\title{
Needs, Rights and Responsibilities in Water Governance: Some Reflections
}

\author{
Synne Movik
}

\begin{abstract}
This article discusses needs, rights and responsibilities with regard to water, drawing on global discourses and cases from South Africa. Taking the New Delhi and Dublin Statements as a point of departure, it describes the prevalent global discourses and sets of dichotomies that have characterised much of the water governance debates, such as human right/economic good, public/private, formal/informal, etc. It explores the boundaries of responsibilities between actors, and argues that, rather than an 'either/or' approach, new constellations of governance arrangements need to be sought in urban and rural settings, that acknowledge the differential needs of people and communities. While water is a public, justiciable socioeconomic good, the provision of which should lie ultimately with the government, there are myriad constellations across the spectrum of public to private provision that can meet the challenges. The dichotomies, and in particular the idea of 'public' and 'private', are only useful to a limited extent, as there are many 'publics' and many 'privates'. The question is not so much who offers the service, but how it is offered or organised, how and by whom needs are defined and contested, to what extent needs are met or not, and how clear lines of accountability are established.
\end{abstract}

\section{Introduction}

At the end of the UN-declared International Drinking Water Supply and Sanitation Decade (1981-90), the General Assembly of the United Nations endorsed the New Delhi Statement (United Nations 1990), which resulted from the work of the Global Consultation on Safe Water and Sanitation. The guidelines contained in the declaration emphasised: (i) the protection of the environment and safeguarding of health through the integrated management of water resources and liquid and solid wastes; (ii) the need for institutional reforms promoting an integrated approach, including the full participation of women at all levels in sector institutions;

(iii) community management of services; and (iv) ensuring sound financial practices. A couple of years later, the International Water and Environment Conference in Dublin produced the 'Dublin Principles'. These included recognising that: (a) water is a finite resource; (b) that water management should be participatory; (c) that women play an important role; and (d) that water should be recognised as an economic good in all its competing uses.
Even though integration was explicitly mentioned in the Delhi Statement, it is the Dublin Principles that have been cast as being at the heart of Integrated Water Resources Management (IWRM) (GWP 1992), which was defined by the Global Water Partnership (GWP) in 2000, as 'a process which promotes the coordinated development and management of water, land and related resources, in order to maximize the resultant economic and social welfare in an equitable manner without compromising the sustainability of vital ecosystems'. IWRM grew to become an allencompassing framework for water resources management, easing its way into national policies and plans - but not without criticism. Biswas (2004: 250) pointed out that the term was vague and open to multiple interpretations, essentially rendering it 'un-implementable', whereas Molle (2008) dubs it a 'nirvana concept', and that its usage lacks coherence. Although IWRM contains some clear principles, such as the notion that water should be managed according to hydrological boundaries, a key issue is the absence of clarity of precisely what it is that should be integrated, and at what scale. 
Meanwhile, in parallel with the output of reams of papers and policies dealing with IWRM, debates were becoming increasingly polarised with regard to water supply and sanitation. This is perhaps best illustrated through the reaction to the idea of water as an economic good, the Dublin principle that really caught the eye of the public. It spurred scholars and practitioners into arguing over the merits and demerits of viewing water as an economic good or as a human right (Briscoe 1997; Perry et al. 1997; McNeill 1998). Associated with these debates, the questions of whether water should be provided through public or private means was brought to the fore, in turn giving rise to high-profile anti-privatisation campaigns (Shrybman 2002). One might muse that what some felt to be a lack of clarity on the issue of IWRM somehow nurtured these polarised debates; that framing water services debates in dichotomous terms provided an antidote to the fuzzy idea of integration.

\section{Teasing apart the dichotomies, and mapping out needs, rights and responsibilities}

These dichotomous framings of water and water management as taking one form or another of a set of alternatives - an economic good vs a human right; public vs private; of informal vs formal; of service vs resource - have all been quite persistent, but are giving way to the emergence of new framings and ways of appraising water institutions and governance arrangements that are helping to break down such polarisations.

For example, with regard to viewing water as a human right or as an economic good - water does have economic value in competing use. There is not necessarily a contradiction between that observation and arguing that access to water is a human right. Water is an economic good when choices are made whether to allocate it to this rather than that particular use; whether it is allocated through administrative use rights, or through marginal pricing or through the market (Dinar et al. 1997). The idea of 'economic good' implies that water resources are scarce and need to be allocated according to market principles. However, water may be traded, bought and sold in times of non-scarcity as well, and hence, the concept of water as a 'commodity' is perhaps more appropriate. The other aspect is that of recovering the costs of service provision. As long as affordability is a key guiding criterion, there is not necessarily an inherent contradiction here either. The point is that allocating water among different uses and recouping the costs of services is compatible with also ring-fencing water for basic human needs - but it depends on strong and effective regulation and legislation being in place to safeguard that access to basic water is not being compromised. However, regulation is extremely resource-demanding. It took almost 100 years for a coherent system of regulation to emerge in the UK, so there is little point in expecting developing countries to develop functional regulatory systems with unrealistically short time-spans.

Turning to another issue, that of public vs private service delivery, it is intuitively appealing that water should be delivered by public agencies, as it is an (impure) public good (Mehta 2003). But as long as the ultimate responsibility of ensuring citizens' access to adequate and affordable water resources rests with the government, then it is irrelevant who actually takes care of service delivery. Whereas the public provision advocates have argued that, since water is a public good, it should also be provided by public authorities, the private sector enthusiasts have countered that government service has tended to be unreliable, ineffective and corrupt. Private sector delivery, they argue, will ensure a more efficient and reliable service. However, the difficulty of servicing rural populations in scattered areas poses problems for both public and private service delivery alike. As Budds and McGranahan (2003) have pointed out, those who push for privatisation as being more efficient than government-supplied services are not taking into account the more 'difficult' areas such as remote rural communities, where households are scattered and investments in infrastructure and operation and maintenance arrangements cannot benefit from the economies of scale that prevail in most urban areas. Numerous studies comparing the performance of private and public service delivery have failed to come to an unequivocal conclusion with respect to performance (Kirkpatrick et al. 2004; Hall and Lobina 2005). Moreover, the very terms 'private' vs 'public' are often confusing. What is actually meant by 'privatisation'? Where is the boundary between public and private to be drawn? The emergence of public-private partnerships (PPPs) is testimony to the growing hybridisation of public and private (Sikor 2008). 
Hence, rather than engaging in debates about polarised principles, a more promising approach is to see water governance as the mapping out of how needs, rights and responsibilities can be matched in particular contexts. An expansive definition of water governance holds that it is defined by the 'political, social, economic and administrative systems that are in place, and which directly or indirectly affect the use, development and management of water resources and the delivery of water service delivery [sic] at different levels of society' (Water Governance Facility 2012). Governing water resources implies conceptualising how needs should be defined and understood, how these are to be met, and by whom - in short, the needs, rights and responsibilities of different actors in society. So, how should the notion of needs be understood? As survival? As wellbeing? Gleick (1998), in a widely cited paper, argued that the human need for water should be set at a minimum of 50 litres per person per day, and that people should be guaranteed access to water regardless of their social, economic or political position. Falkenmark (1997, cited in Woodhouse and Langford 2009: 7) argues that 100 litres is more appropriate for a 'decent and realistic quality of life in developing countries'. How needs are met during a day-to-day basis varies enormously, and may not fit well with an idealised picture of a typical citizen - therefore, some argue that due to the diversity and cultural specificity of human needs, it is next to impossible to agree on a set standard or threshold (see, e.g. Woodhouse and Langford 2009 , for a discussion of a universal vs contextual understanding). Needs are diverse, and people living in rural areas have very different needs from those in urban or peri-urban areas.

Rather than regarding water mainly, or merely, for drinking or personal hygiene, it is increasingly acknowledged that water for livelihoods is a more appropriate way of conceptualising water needs in rural areas. That water is a multiple-use and multi-purpose resource, where the boundaries between water for productive activities or domestic consumption are not clear-cut (De Lange and Cousins 2006; Van Koppen et al. 2006), serves to break down yet another dichotomy, of viewing water as a service and water as a resource. The way that needs are defined and understood will shape the idea of rights. There is a steadily growing literature on the issue of socioeconomic rights, and the idea that governments have obligations to ensure the realisation of 'positive' second-order rights is gaining traction (see, e.g. Jones and Stokke 2005; Liebenberg 2005). Last year, the United Nations General Assembly declared that access to safe and clean drinking water and sanitation was to be considered a human right that was 'essential to the full enjoyment of life and all other human rights' (United Nations 2010: 2). ${ }^{1}$ With respect to the responsibility of ensuring that the human right to water is realised, the recently appointed Independent Expert on Human Rights, Catarina de Albuquerque, reaffirms that the ultimate responsibility of realising rights in a progressive fashion should rest with the state, but emphasised that other parties, such as the private sector, also have a responsibility to ensure that rights are met (UN Human Rights Council 2010). Hence, the increased reference to 'governance' implies that actors - non-governmental organisations (NGOs), communities, private companies - need to be clearly identified in terms of their share of responsibility for ensuring that rights are realised.

\section{Reflections from South Africa}

Water has been high on the agenda in South Africa following the end of apartheid. The White Paper on Water and Sanitation was published in 1994, in the year of transition (DWAF 1994). The goal was to ensure that 'all South Africans had access to essential basic water supply and sanitation services at a cost which is affordable both to the household and to the country as a whole' (DWAF 1994: 1). Water was recognised as a human right in the 1996 Constitution, putting South Africa in the vanguard in the global context. Two reform-minded pieces of legislation: the National Water Services Act 1997, and then the National Water Act 1998, made profound changes to the institutional structures governing water resources and services in South Africa. The motto was 'Some, for All, for Ever', reflecting the Delhi Statement of 'Some for All Rather than More for Some'. A core distinction of the Water Services Act was that between Water Services Authorities and Water Service Providers. Water Services Authorities were by default local government, such as local municipalities, whereas the actual service provision could be contracted out to third parties. In 2001, the policy of 'Free Basic Water' (FBW) was introduced, which promised to provide 6,000 litres of water per 
household per month free of charge, to be partly funded through the Equitable Share, a government grant that redistributes tax revenue from the central government to the provinces and municipalities. This was designed to help municipalities cover the costs of providing basic services. It is the responsibility of the municipalities to provide services, and whether the FBW policy is specifically targeted at the poor, or applied across-the-board, is at their discretion (Calfucoy et al. 2009; Muller 2008). In an excellent review chapter on the challenges of service provision, Eales (2011) notes that although the division of responsibilities was an elegant one, it did not really work out in practice.

Given the major overhauls of the government administration, with the rolling out of wall-towall local municipalities to replace the old structures of apartheid, it was going to be some time before the local municipalities would be able to shoulder their new responsibilities. In the meantime, therefore, the Department of Water Affairs and Forestry (DWAF) was given the responsibility of tackling backlogs until local government structures were fully operational. ${ }^{2}$ Community-driven projects became a major means through which service delivery was provided, and in particular, the NGO Mvula Trust was very effective working on the ground with community-based organisations. However, these projects were eventually phased out, as the local municipalities took on the task of service provision. But the pressure to realise rights has meant that developments are target-driven and focused on infrastructure development and access, rather than functioning and quality of service delivery. In the urge to reach universal coverage, the ability to actually meet needs is compromised, and protests over service delivery failure are rife.

\subsection{Redefining needs and rights: the Phiri case}

Most of South Africa's water services are publicly provided and only five municipalities have chosen private providers, although the attention that the cases of privatisation have received sometimes makes this fact less visible. There is a strong anti-privatisation movement in South Africa, which holds that privatisation works against the poor. This is indeed often the case, but it need not necessarily be so, provided regulation is in place. There is no inherent contradiction between the right to water and a private provider. The problem is, however, when providers resort to disconnections and steep price hikes. The dimensions of rights apart from quantity - quality, access and affordability - need to be realised. The now-famous Mazibuko vs City of Johannesburg case is a testimony to the amount of attention prevailing.

\section{In 2008, Lindiwe Mazibuko, a citizen of Phiri,} Soweto, brought a claim against the City of Johannesburg. She argued that the free basic water supply was not enough to meet the needs of her household, which consisted of 16 people, some of whom were suffering from HIV, and that the use of pre-paid meters was unconstitutional. The High Court ruled in favour of Mazibuko, stating that '25 litres per person per day is insufficient for the residents of Phiri ... to expect the applicants to restrict their water usage, to compromise their health, by limiting the number of toilet flushes in order to save water is to deny them the rights to health and to lead a dignified lifestyle' (Polaris Institute 2008). The city appealed, and the case was taken to the Supreme Court.

The Constitutional Court decided the case on 8 October 2009. In a surprise turnaround, they supported the defendants on both counts. Whereas the High Court deemed that 50 litres was more appropriate in meeting real needs, this quantity was reduced by the Supreme Court ruling to 42 litres per day, and was further reduced to the 25 litres per day with the Constitutional Court ruling. The final ruling stated that the mandate to determine what was an appropriate quantity of water to satisfy human need was not within the mandate of the Court, but of the government. Furthermore, it stated that the use of prepaid meters was not unconstitutional. The Phiri case shows how service providers may fall far short of ensuring that the human right to water is met, and how government may fail in following-up on the rights-based approach (Mehta and Ntshona 2004). But even more than a failure of service provision, the Phiri case is first and foremost an example of judicial failure - in particular relating to the interpretation of needs. As Williams (2009) argues, in terms of the principles of separation of powers, it is the prerogative of the representative branches to assign quantitatively specific values to social and economic rights. The High Court ruling was an excellent example of how the human right to 
water could have been upheld and expanded, through its capability-oriented understanding (Sen 1999) of the concept of basic human needs.

\subsection{Whose responsibility is it, anyway? Bringing communities back in}

A capability view of water as a human right acknowledges that needs are diverse. People will have different needs depending upon where they live and what their livelihoods are. The multipleuse systems (MUS) approach takes account of this diversity. Apart from the challenges in implementing MUS in terms of appropriate infrastructure, etc. there are also potential legal hindrances. A strict reading of the Water Services Act (Act 108 of 1997) and the National Water Act (NWA) reveals that they are contradictory with respect to water for domestic uses - whereas the NWA includes a category of use rights called 'Schedule One', which is meant to apply to smallscale domestic uses, home gardening, and watering livestock, the Water Services Act states that water for domestic use 'should be provided by an authorized service provider' (Kahinda et al. 2007). It also differs on the responsibility. For instance, whereas the 2003 Strategic Framework states that municipalities have the obligation to provide water for livelihood purposes, the Municipal Services Act takes a stricter view, arguing that the mandate of the municipality should be limited to providing sufficient service to meet basic needs) (Naidoo 2009). Given that the minimum threshold of water should be a floor rather than a ceiling, this means that it is open to contextualisation. For instance, in many rural areas, for example in the Bushbuckridge area of Mpumalanga, there is some potential for households to draw on alternative water sources through, for example the use of rainwater harvesting tanks or other storage facilities or sources of water (Cousins et al. 2007). In contrast, people living in urban areas or townships mostly do not have access to such alternative sources, and are often entirely reliant on water service provision. Considering the challenges faced by local municipalities, and the points discussed above, it seems prudent to explore ways in which to bring communities back into management of service delivery in an appropriate form. The benefits of community managed services would be that it would likely avoid the 'dependency' dilemma through taking on partial responsibility. In the rural areas, it is as much a geographical issue, as individuals and communities may be living far away from service centres. Communitybased water harvesting initiatives is but one example of how communities could be involved in meeting their own water needs. However, community involvement is of course no panacea, and brings problems of its own. For instance, devolving power to communities might be seen as a way of relieving local government of their duties with respect to service provision. Intracommunity power dynamics may hinder access of individuals, which runs counter to the idea of human rights. Still, given the positive experiences from past community-driven projects, the benefits of involving communities are likely to outweigh the drawbacks.

\section{From dichotomies to pathways}

The continuum along which rights, needs and responsibilities are clustered, implies that it is misplaced to talk about either/or - either treating water as an economic good or as a human right; either going for private as opposed to public service provision. This article argues in favour of a contextual understanding not only of needs and rights, but also of responsibilities. As long as the overall responsibility remains with the government, questions of capacity and the nature of the existing institutional structures will to a great extent determine what sort of arrangements will be feasible and desirable in a given setting. The examples from South Africa serve to underscore this. Opening for a broader understanding of what rights should constitute, and adhering to a 'floor' understanding of the human right rather than a ceiling, this ties in with the idea that water is central to wellbeing, not only survival. However, broadening up the understanding of what comprises a right also implies that the understanding of whose responsibility it is to ensure that right should be broadened up as well. Moreover, the realisation of socioeconomic rights is a form of voicing public concern and mobilising around particular issues of importance to the citizenry. This brings into view the often rather wide gaps between global and national definitions of rights, and contextual understandings of what rights should comprise. Also, there is a risk that the adoption of rights-based approaches may be hollowed out by considerations of cost. A stark illustration of this in the South African context was when the city of Cape Town installed open toilets in the township of Khayelitsha in 2009, but expected households to pay for enclosures, which many 
could not afford. Issue of cost is also a clear issue in the Phiri case. Jones and Stokke (2005) argue that the conceptualisation and implementation of socioeconomic rights contribute to building democratic capacity. Thus, it is not only the definition of needs and rights, and the negotiations over responsibility per se, but as much about the process of defining needs and engaging in rights-claiming and delimiting responsibility as well. Thus, it makes sense to move away from a discussion of choices between sets of dichotomies to a more pragmatic-oriented approach that takes into account the existing

\section{Notes}

1 Several representatives abstained on the grounds that the declaration of such a right was 'premature' until a firm international agreement was in place.

2 DWAF has been concerned with water resource management and infrastructure development. Second-tier management was delegated to government-owned water boards, which operate dams, bulk water supply

\section{References}

Biswas, A.K. (2004) 'Integrated Water Resources Management: A Reassessment', Water International 29.2: 248-56

Briscoe, J. (1997) 'Managing Water as an Economic Good', in M. Kay, T. Franks and L. Smith (eds), Water: Economics, Management and Demand, London: E \& FN Spon

Budds, J. and McGranahan, G. (2003) 'Are the Debates on Water Privatization Missing the Point? Experiences from Africa, Asia and Latin America', Environment and Urbanization 15.2: 87-114

Calfucoy, P.; Gibulka, J.; Davison, J.; Hinds, T. and Park, M. (2009) Improving Free Basic Water Provision in South Africa, report prepared for the Financial and Fiscal Commission, Republic of South Africa

Cousins, T.; Smits, S. and Chauke, T. (2007) South Africa: Access to Water and Livelihoods in Ward 16, Bushbuckridge, www.musgroup.net/home/ activities/the_cpwf_mus_project/basins countries/limpopo_basin_cpwf_mus_studies/ limpopo_basin_outputs/south_africa_access_ to_water_and_livelihoods_in_ward_16 bushbuckridge/(language)/eng-GB (accessed 5 December 2011)

De Lange, M. and Cousins, T. (2006) Using Water to Fight Poverty: A Multiple-Use Systems Approach realities on the ground, and the extent of needs and capacities. In that sense, the New Delhi Statement is perhaps the most suitable. Still, there is space for a broader definition of responsibilities, not least involving the national community. The United Nations Declaration of a Human Right to water is the start of such a process. Building on the Delhi principles, and fleshing out a flexible framework that allows the mapping out of needs, rights and responsibilities in each country context, whilst at the same time remaining clear with regard to government responsibility, seems a promising way forward.

infrastructure - they also play an important role in water resources management through their involvement in dam operations. A third tier of management was now added to DWAF's mandate (e.g. in the former homelands), but water administrations in towns and cities remained with existing administrations.

to Food Security and Productive Uses of Water, www.musproject.net (accessed 5 December 2011)

Dinar, A.; Rosegrant, M.W. and Meinzen-Dick, R. (1997) Water Allocation Mechanisms: Principles and Examples, Policy Research Working Paper 1779, Washington DC: World Bank

DWAF (1994) Water Supply and Sanitation Policy White Paper, Cape Town: Department of Water Affairs and Forestry

Eales, K. (2011) 'Water Services South Africa 1994-2009', in B. Schreiner and R. Hassan (eds), Transforming Water Management in South Africa: Designing and Implementing a New Policy Framework, New York: Springer, 33-73

Gleick, P.H. (1998) 'The Human Right to Water', Water Policy 1: 487-503

GWP (2000) Integrated Water Resources Management, Technical Advisory Committee (TAG) Background Papers 4, Stockholm: Global Water Partnership

GWP (1992) Dublin-Rio-Principles, www.gwp.org/ The-Challenge/What-is-IWRM/Dublin-RioPrinciples/ (accessed 5 December 2011)

Hall, D. and Lobina, E. (2005) The Relative Efficiency of Public and Private Sector Water, report commissioned by Public Services International (PSI), London: Public Services International Research Unit (PSIRU), University of Greenwich 
Jones, P.S. and Stokke, K. (2005) 'Introduction: Democratising Development: The Politics of Socio-Economic Rights in South Africa', in P. Jones and K. Stokke (eds), Democratising Development: The Politics of Socio-Economic Rights in South Africa, Leiden: Martinus Nijhoff Publishers: 1-38

Kahinda, J.-M.M.; Taigbenu, A.E. and Boroto, J.R. (2007) 'Domestic Rainwater Harvesting to Improve Water Supply in Rural South Africa', Physics and Chemistry of the Earth 32.15-18: 1050-7

Kirkpatrick, C.; Parker, D. and Zhang, Y.-F. (2004) State Versus Private Sector Provision of Water Services in Africa: A Statistical, DEA and Stochastic Cost Frontier Analysis, Working Paper Series 70, Manchester: Centre on Regulation and Competition (University of Manchester)

Liebenberg, S. (2005) Needs, Rights and Transformation: Adjudicating Social Rights, Center for Human Rights and Global Justice Working Paper, Economic and Social Rights Series, New York: New York University

McNeill, D. (1998) 'Water as an Economic Good', Natural Resources Forum 22.4: 253-61

Mehta, L. (2003) 'Problems of Publicness and Access Rights: Perspectives from the Water Domain', in I. Kaul, P. Conceição, K. Le Goulven and R.U. Mendoza (eds), Providing Global Public Goods: Managing Globalization, Oxford: Oxford University Press

Mehta, L. and Ntshona, Z. (2004) Dancing to Two Tunes? Rights and Market-based Approaches in South Africa's Water Domain, Sustainable Livelihoods in Southern Africa (SLSA) Research Papers 17, Brighton: IDS

Molle, F. (2008) 'Nirvana Concepts, Narratives and Policy Models: Insight from the Water Sector', Water Alternatives 1.1: 131-56

Muller, M. (2008) 'Free Basic Water: A Sustainable Instrument for a Sustainable Future in South Africa', Environment and Urbanization 20.1: 67-87

Naidoo, G. (2009) Leadership and Good Governance in Public Administration. A Critical Need for Transformative African Leadership and Good Governance for Adoption by the South African Public Service, Saarbrücken: VDM Verlag Muller Aktiengesellschaft \& Co. KG
Perry, C.J.; Rock, M. and Seckler, D. (1997) Water as an Economic Good: A Solution, or a Problem?, IWMI Research Report 14, Colombo: International Water Management Institute

Polaris Institute (2008), Johannesburg High Court Declares Prepaid Water Meters Unlawful and Unconstitutional, www.polarisinstitute.org/ johannesburg_high_court_declares_prepaid_ water_meters_unlawful_unconstitutional (accessed 5 Décember 20-11)

Sen, A. (1999) Development as Freedom, Oxford: Oxford University Press

Shrybman, S. (2002) Thirst for Control, Analysis and legal opinion prepared for the Council of Canadians

Sikor, T. (2008) Public and Private in Natural Resource Governance: A False Dichotomy?, London: Earthscan

UN Human Rights Council (2010) Report of the Independent Expert on the Issue of Human Rights Obligations Related to Access to Safe Drinking Water and Sanitation, Catarina de Albuquerque, Geneva: United Nations

United Nations (2010) United Nations General Assembly Resolution 64/292, The Human Right to Water and Sanitation, New York: United Nations

United Nations (1990) New Delhi Statement, Global Consultation on Safe Water and Sanitation, 1990, www.ielrc.org/content/e9005.pdf (accessed 1 December 2011)

Van Koppen, B.; Moriarty, P. and Boelee, E. (2006) Multiple-Use Water Services to Advance the Millennium Development Goals, IWMI Research Report 98, Colombo: International Water Management Institute

Water Governance Facility (2012) What is Water Governance?, www.watergovernance.org/sa/ node.asp? node $=846$ (accessed 5 December 2011)

Williams, L.A. (2009) 'The Justiciability of Water Rights: Mazibuko v. City of Johannesburg', Forum for Development Studies 36.1: 5-48

Woodhouse, M. and Langford, M. (2009) 'Crossfire: There is no Human Right to Water for Livelihoods', Waterlines 28.1: 5-12 